Article

\title{
Enhancement of Biofilm Formation on Pyrite by Sulfobacillus thermosulfidooxidans
}

\author{
Qian Li, Wolfgang Sand and Ruiyong Zhang * \\ Biofilm Centre, Aquatische Biotechnologie, Universität Duisburg—Essen, Universitätsstraße 5, \\ 45141 Essen, Germany; liqian064x@126.com (Q.L.); wolfgang.sand@uni-due.de (W.S.) \\ * Correspondence: ruiyong.zhang@uni-due.de; Tel.: +49-201-183-7076; Fax: +49-201-183-7088 \\ Academic Editor: W. Scott Dunbar \\ Received: 29 April 2016; Accepted: 4 July 2016; Published: 9 July 2016
}

\begin{abstract}
Bioleaching is the mobilization of metal cations from insoluble ores by microorganisms. Biofilms can enhance this process. Since Sulfobacillus often appears in leaching heaps or reactors, this genus has aroused attention. In this study, biofilm formation and subsequent pyrite dissolution by the Gram-positive, moderately thermophilic acidophile Sulfobacillus thermosulfidooxidans were investigated. Five strategies, including adjusting initial $\mathrm{pH}$, supplementing an extra energy source or ferric ions, as well as exchanging exhausted medium with fresh medium, were tested for enhancement of its biofilm formation. The results show that regularly exchanging exhausted medium leads to a continuous biofilm development on pyrite. By this way, multiply layered biofilms were observed on pyrite slices, while only monolayer biofilms were visible on pyrite grains. In addition, biofilms were proven to be responsible for pyrite leaching in the early stages.
\end{abstract}

Keywords: bioleaching; Sulfobacillus thermosulfidooxidans; biofilm formation

\section{Introduction}

The term of bioleaching refers to mobilization of metal cations from insoluble ores by microorganisms [1,2]. Leaching can be done by microorganisms via two ways: contact and non-contact leaching. Ferric ions are of great importance in both of these two ways. As an oxidizing agent, ferric ions in acidic environments readily oxidize metal sulfides and cause the release of ferrous ions and reduced inorganic sulfur compounds (RISCs). Ferrous ions can be re-oxidized to ferric ions by iron-oxidizing bacteria, and RISCs can be oxidized to sulfuric acid by sulfur-oxidizing bacteria. Thus, minerals get dissolved [3]. Comparing the two ways, contact leaching is seen to be more efficient. This may be because extracellular polymeric substances (EPS), secreted by bacteria, accumulate ferric ions via complexation and decrease the reaction distance between the cells and the mineral surface [4].

During the last several decades, bioleaching has already been applied worldwide industrially for recovering metals from low grade ores [5]. Instead of a sole species, microbial populations exhibited substantial diversity in stirred-tank, mineral-processing bioreactors and ore leaching heaps. Microbial community analysis of the leachate has shown that the microbial bioleaching communities varied in commercial mineral leaching operations, but the genus of Sulfobacillus can be detected frequently [6-8]. The genus Sulfobacillus was first reported by Golovacheva and Karavaiko in 1978 [9]. Until now, there have been five species classified into this genus based on phylogenetic and physiological characteristics: Sb. thermosulfidooxidans, Sb. acidophilus, Sb. thermotolerans, Sb. sibiricus and $S b$. benefaciens. Among them $S b$. thermosulfidooxidans is the most studied species. The sulfobacilli are Gram-positive, generally non-motile, rod shaped, endospore-forming and moderately thermophilic acidophiles. They can oxidize ferrous iron, RISCs such as tetrathionate, thiosulfate and elemental sulfur, as well as sulfide minerals in the presence of $0.02 \%$ yeast extract. 
Because of the versatile metabolism and tolerance to a hostile environment characterized by low $\mathrm{pH}$ and high metal concentrations, the genus Sulfobacillus has been considered for optimization of microbial consortia [10], and they are crucial in mixed cultures during leaching. It is reported that the smaller proportion of Sulfobacillus in leaching consortia under continuous conditions was correlated with the reduction of chalcopyrite leaching kinetics than in batch mode. Spolaore et al. [11] compared chalcopyrite leaching efficiency of an undefined leaching consortia under continuous condition with that in batch mode. The results show that the leaching kinetics in the continuous test were lower than in the batch test, which can be attributed to a smaller proportion of Sulfobacillus, in agreement with Foucher et al. [12]. Extensive oxidization of metal sulfides by biofilms of Sb. thermosulfidooxidans was indicated by the etch pits appearing within $94 \mathrm{~h}$ on pyrite surfaces [13]. All of these studies indicate that the biofilm formation by Sulfobacillus probably leads to a high mineral dissolution rate. Thus, it is worth studying the adhesion of Sulfobacillus to mineral surfaces and enhancing their biofilm formation on them.

Initial adhesion of planktonic cells to a surface is the first step in biofilm formation [14]. It is induced by biological and physicochemical interactions between cells and substratum [15,16]. Cells interact with the environment by their surface, and the environment affects cell surface properties. The energy source can influence the chemical composition of EPS and cause changes of cell surface hydrophobicity and charge. As a consequence, bacterial cells grown on different energy sources exhibit different attachment ability to the same substratum [4,17]. In view of the effect from the culturing environment, five strategies were chosen to test their effects on enhancement of biofilm formation by $S b$. thermosulfidooxidans DSM $9293^{\mathrm{T}}$ on pyrite: changing medium $\mathrm{pH}$, supplementing an extra energy source, adding ferric ions, phosphate starvation and exchanging exhausted medium with fresh medium. Epifluorescence microscopy (EFM), confocal laser scanning microscopy (CLSM) and atomic force microscopy (AFM) were used for monitoring cell attachment and biofilm formation as well as microorganism-pyrite interface structures. This study first demonstrates a method for enhancing biofilm formation by Gram-positive acidophiles and provides a hint of interfacial interactions between these bacteria and pyrite.

\section{Materials and Methods}

\subsection{Strain and Growth Conditions}

$\mathrm{Sb}$. thermosulfidooxidans ${ }^{\mathrm{T}}$ was grown on $3 \%$ pyrite $(\mathrm{m} / \mathrm{v})$ with $0.02 \%$ yeast extract in a medium at $\mathrm{pH} 2.5$, the medium was prepared according to Mackintosh et al. [18]. The culture was incubated at $45{ }^{\circ} \mathrm{C}$ on a rotary shaker at $150 \mathrm{rpm}$. Cells were harvested by centrifugation at $11,270 \mathrm{~g}$ for $10 \mathrm{~min}$. Cell numbers were determined by directly counting with a Thoma chamber (Assistent ${ }^{\circledR}$, Sondheim v. d. Rhön, Germany).

\subsection{Preparation of Pyrite Grains and Pyrite Slices}

Pyrite grains with a size of 100-200 $\mu \mathrm{m}$ were used after wet-sieving floatation pyrite from Romania. Pyrite slices were cut off from pyrite cubes with a size of $1 \mathrm{~cm} \times 1 \mathrm{~cm} \times 1 \mathrm{~cm}$ (Museum grade, Freiburg, Germany). These pyrite cubes were naturally crystallized, and their six sides were smooth and shiny. After cutting, slices with one shiny side and one rough side were obtained, and this study only focused on the shiny side. No clear cell-shaped pits were observed by atomic force microscopy (AFM) (Supplementary Materials, Figure S1). Pyrite grains and slices were cleaned and sterilized as described before [19].

\subsection{Strategies for Enhancing Biofilm Formation}

Different initial medium $\mathrm{pH}$ was adjusted with $1 \mathrm{M} \mathrm{H}_{2} \mathrm{SO}_{4}$ or $\mathrm{KOH}$. In addition, $10 \mathrm{mM}$ ferric chloride, $50 \mathrm{mM}$ potassium tetrathionate, and sodium thiosulfate were prepared as a standard solution and sterilized by filtration. Phosphate starvation was conducted by using phosphate free MAC medium. 
Medium replacement was performed by exchanging fresh MAC medium containing $0.02 \%$ yeast extract with exhausted medium every two days. The experiments were conducted in $300 \mathrm{~mL}$ flasks with $3 \%$ pyrite in $150 \mathrm{~mL}$ MAC medium. The initial cell density for all experiments was $2 \times 10^{8}$ cells $/ \mathrm{mL}$, which was achieved by inoculating a calculated volume of the cell suspension. The cells were inoculated prior to pyrite addition, and the precise initial cell density could be determined. Regular medium exchange without cell inoculation was set as an abiotic control. All assays were done in triplicate.

\subsection{AFM, EFM and CLSM}

For visualization of the cell distribution on pyrite surfaces, nucleic acid staining was applied. The staining procedures described as follows. Pyrite grains and pyrite slices were first rinsed with sterile MAC medium and then with MilliQ water (Merck Millipore, Schwalbach, Germany). Afterwards, they were immersed in $6 \mu \mathrm{M} \mathrm{SYTO}^{\circledR} 9$ for $15 \mathrm{~min}$. Another rinsing with MilliQ water three times was done after staining in order to remove unbound dye.

A laser scanning module (LSM 510 Carl Zeiss ${ }^{\circledR}$ Jena, Jena, Germany) combined with an inverted Axiovert100 M BP microscope (Zeiss ${ }^{\circledR}$, Hallbergmoos, Germany) was used for biofilms visualization. MosaiX module was especially applied for visualizing biofilm development on pyrite slices. This program can provide information in one image by integrating several images. In this study, $25(5 \times 5)$ images were integrated.

In order to further observe architecture of biofilms, a NanoWizard II AFM (JPK Instruments, Berlin, Germany) in contact mode in liquid was used. Experiments were conducted in pH 2.5 MAC medium. A CSC38/NO AL (Mikromasch, Tallinn, Estonia) probe was also used and cantilever B with the following parameters were chosen for scanning: typical length, $350 \mu \mathrm{m}$; width, $32.5 \mu \mathrm{m}$; thickness, $1.0 \mu \mathrm{m}$; resonance frequency, $10 \mathrm{kHz}$; and force constant, $0.03 \mathrm{~N} / \mathrm{m}$. The applied setpoint was $1 \mathrm{~V}$ and the scan rate was $0.5 \mathrm{~Hz}$.

\section{Results and Discussion}

\subsection{Biofilm Formation of Sb. thermosulfidooxidans on Pyrite under Standard Conditions}

After $4 \mathrm{~h}$ of incubation, only $30 \%$ of the cells attached to pyrite grains (Figure 1A). This indicates a low attachment ability of $S b$. thermosulfidooxidans to pyrite. A few cells can be visualized on pyrite grain surface after $1 \mathrm{~d}$ incubation, and their distribution was heterogeneous (Figure 1B). It became more and more difficult to find attached cells in the following days, and, after $20 \mathrm{~d}$, no attached cells remained (Figure 1C,D). The same results were obtained when pyrite slices were used as substratum (Figure 2). Although there were many cells or big flocs on the surface after $1 \mathrm{~d}$ incubation, cells were all detached after $14 \mathrm{~d}$ incubation. A lack of motility might be one reason for the low amounts of attached cells and the badly formed biofilm on pyrite. Redistribution of attached cells by surface motility, binary division of attached cells, and recruitment of cells from the bulk fluid are the mechanisms of biofilm formation [14]. It is well known that leaching bacteria prefer to colonize on imperfections of mineral surface, where the crystal structure can be easily destroyed [3,20]. Because of a lack of motility, Sb. thermosulfidooxidans attached to the pyrite surface by chance, thus not all the attached sites were suitable for further colonization. Cell detachment might occur, which leads to the poor biofilm formation. In addition, many publications emphasized the importance of motility for the biofilm formation [21,22]. When cells were incubated with pyrite slices, large flat surfaces and reduced shearing forces provide a chance to facilitate their attachment on the surface. However, these cells detach during the course of the experiment, and, finally, almost no cells were detectable. 


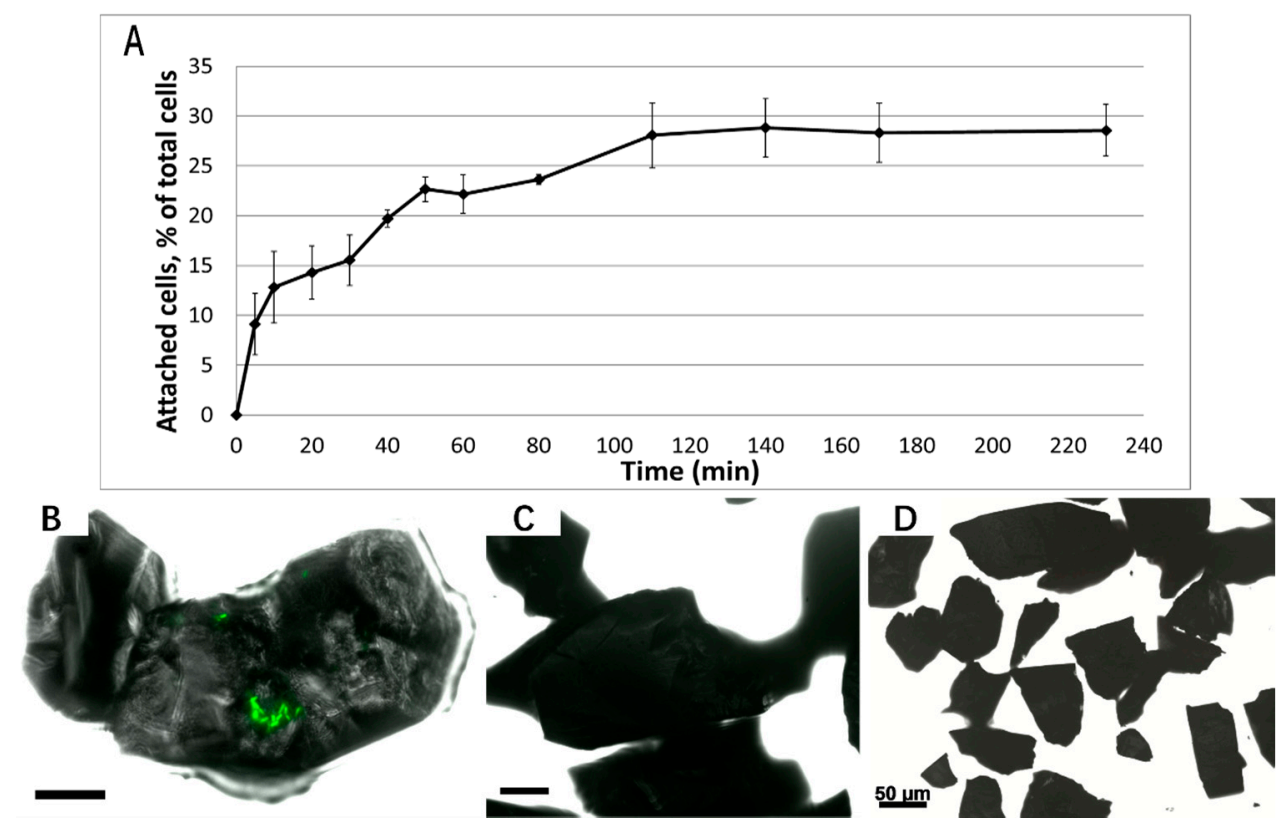

Figure 1. Amounts of attached cells of Sb. thermosulfiooxidans to pyrite grains within $4 \mathrm{~h} \mathrm{(A)}$ and their biofilm development on pyrite grains after one day (B); 20 days (C) and 40 days (D) incubation. Scale bar, $20 \mu \mathrm{m}$.
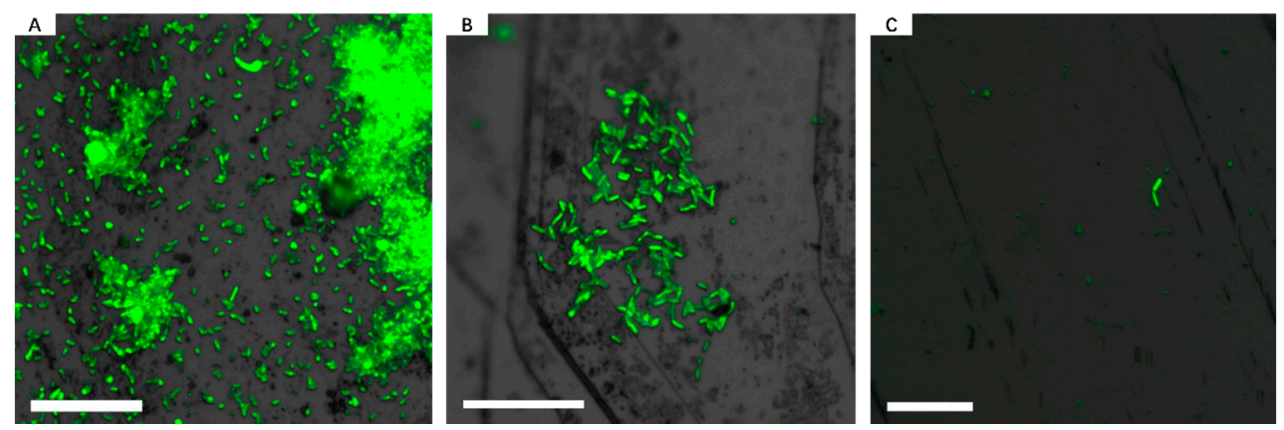

Figure 2. Biofilms of $S b$. thermosulfiooxidans on pyrite slice after one day (A); seven days (B) and 14 days (C) incubation. Scale bar, $20 \mu \mathrm{m}$.

\subsection{Effect of Different Strategies on Enhancement of Biofilm Formation by Sb. thermosulfidooxidans on Pyrite}

The initial medium $\mathrm{pH}$ can regulate sporulation. Even changes of one unit of $\mathrm{pH}$ may increase sporulation [23]. Sb. thermosulfidooxidans was reported to have the best ferrous ion oxidation at $\mathrm{pH} 1.4$. A significant reduction of ferrous ion oxidation rate was observed if the $\mathrm{pH}$ varied in the range of 1.0-3.0 [24]. Thus, we studied and compared the biofilm formation of $S b$. thermosulfidooxidans at initial $\mathrm{pH} 1.5$ and 3.5. The epifluorescence microscopy (EFM) images (Figure 3A,B) indicate that no cells were attached on pyrite grains either at $\mathrm{pH} 1.5$ or 3.5 after one week. Although some green dots on pyrite surface were detectable, when cells were grown at $\mathrm{pH} 1.5$, these dots were most likely not cells as indicated by shape and size. The finding demonstrates that variation of initial $\mathrm{pH}$ cannot stimulate cell adhesion and biofilm formation. 


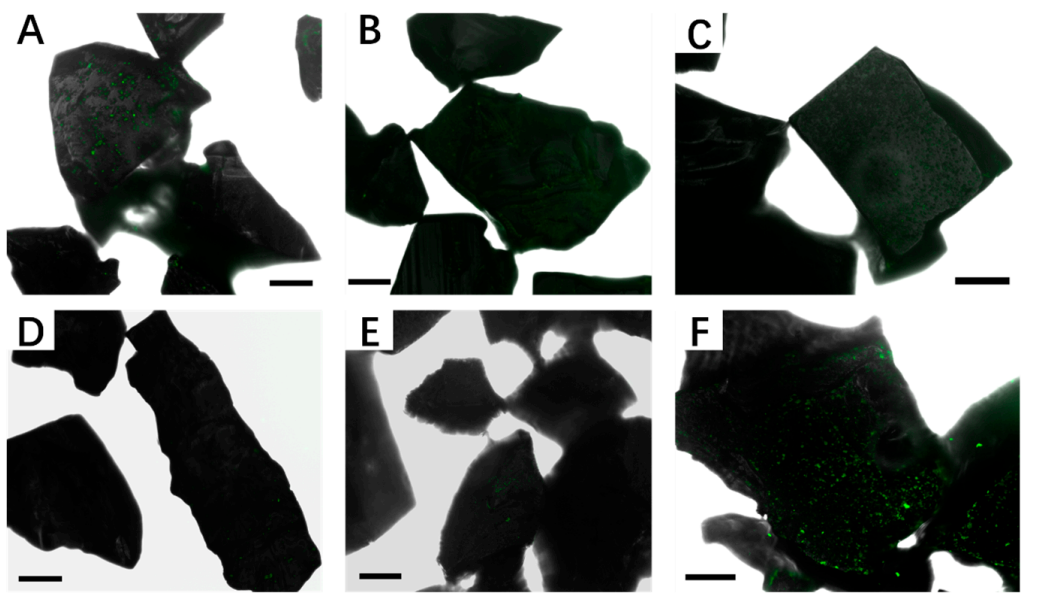

Figure 3. Biofilms of $\mathrm{Sb}$. thermosulfiooxidans on pyrite grains after one week of incubation with initial $\mathrm{pH}$ 1.5 (A) or 3.5 (B); or with $2 \mathrm{mM} \mathrm{K}_{2} \mathrm{~S}_{4} \mathrm{O}_{6}\left(\right.$ C); $2 \mathrm{mM} \mathrm{Na}_{2} \mathrm{O}_{3} \mathrm{~S}_{2} \cdot 5 \mathrm{H}_{2} \mathrm{O}$ (D) or $1 \mathrm{mM} \mathrm{FeCl}_{3}$ (E) supplanted, or under condition of phosphate starvation (F). Scale bar, $20 \mu \mathrm{m}$.

A recent study indicated that not planktonic but biofilm cells of Acidithiobacillus ferrooxidans ${ }^{\mathrm{T}}$ made contributions to pyrite dissolution within the first 4-5 days after inoculation [25]. Accordingly, we may speculate that biofilms of $S b$. thermosulfidooxidans on pyrite grains did not have a sufficient supply of energy, which resulted in starvation triggering sporulation or dormancy. Thus, $2 \mathrm{mM}$ tetrathionate or thiosulfate were supplemented as extra energy source. However, neither of them showed a positive effect on enhancement of biofilm formation (Figure 3C,D).

Ferric ions contribute to leaching as oxidizing agent [26], but also play a role in initial adhesion. The complexed iron ions in EPS provide a positive charge on the cell surface inducing cells to adhere to negatively charged pyrite surfaces via electrostatic attract forces [3,27]. It has been shown that a supplement of $1 \mathrm{mM}$ ferric ions causes a 10 fold increase of the colonization of pyrite by cells of A. ferrooxidans R1 [25]. In our study, ferric ions did not increase adhesion of Sb. thermosulfidooxidans on and colonization of pyrite surfaces (Figure 3E). This could be attributed to low amounts of the ferric iron complexing uronic acids in the tightly-bound EPS of cells of $\mathrm{Sb}$. thermosulfidooxidans (unpublished data).

It is accepted that EPS are a prerequisite for leaching bacteria to attach to solid substrata such as pyrite or elemental sulfur [4]. Thus, inducing EPS production may enhance cell adhesion. Phosphorus is a very important element for organisms, but the response of bacteria to limited phosphate can be different. Phosphorus limitation can increase attachment in case of Agrobacterium tumefaciens [28]. Bellenberg et al. also described that growth under phosphate starvation conditions resulted in an enhancement of EPS production and well-formed biofilms of A. ferrooxidans [29]. However, Pseudomonas fluorescens detached from its substratum surface when growing under low phosphate conditions [30]. From our own images (Figure 3F), it is obvious that after one week of incubation under phosphate starvation conditions, no well-formed biofilms exist on the pyrite grain surfaces and only a few single cells occur, which indicates that phosphate starvation does not significantly enhance biofilm formation.

Exchanging exhausted medium with fresh medium is the only strategy showing a positive effect (Figure 4). This enhancement was reproducible when pyrite slices were applied (Figure 5). However, the architecture of biofilms grown on pyrite slices is different from the one grown on pyrite grains. Comparing the images, we can see that biofilms grown on a pyrite slice display a multiple layer structure (Figure 6), while biofilms grown on pyrite grains display monolayer structure (Figure 4B,C). Strong shear forces in the case of pyrite grains may be the main reason for the different biofilm phenotype.

Enhancement of biofilm formation by Sb. thermosulfidooxidans due to exchanging spent medium may be due to several reasons. One is that the organic supplement facilitates the growth of 
Sb. thermosulfidooxidans. It is well known that Sulfobacilli have a mixotrophic metabolism on $\mathrm{Fe}^{2+}$, $\mathrm{S}^{0}, \mathrm{~S}_{4} \mathrm{O}_{6}{ }^{2-}, \mathrm{S}_{2} \mathrm{O}_{3}{ }^{2-}$ and sulfide minerals in the presence of low amounts of organic compounds. Their autotrophic and heterotrophic growth are poor. The dramatic decrease of planktonic cell numbers of subcultures of $1 \mathrm{~d}$ biofilms of $\mathrm{Sb}$. thermosulfidooxidans (Figure 7) after $50 \mathrm{~h}$ may also indicate that the consumption of the yeast extract caused the decrease in cell density. When fresh medium was supplied, growth continued. The second possibility is the removal of harmful factors in the growth medium, thereby ensuring biofilm formation. A high cell density may trigger sporulation and the formation of persister cells [31].
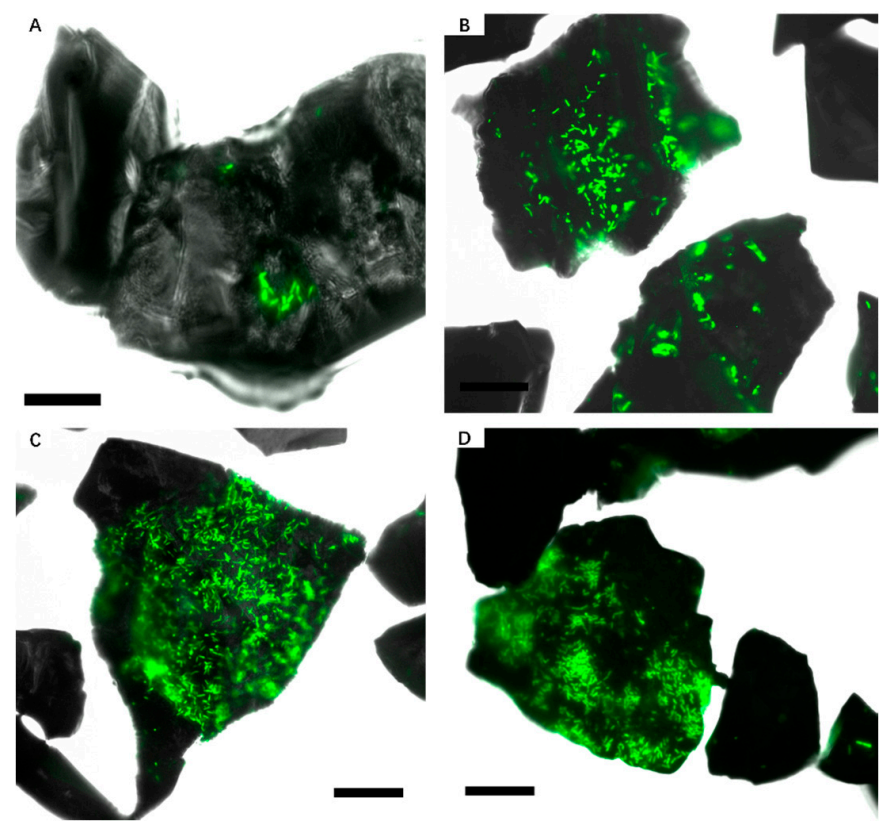

Figure 4. Biofilms of $S b$. thermosulfiooxidans on pyrite grains after one day (A); 20 days (B); 40 days (C) and 60 days (D) incubation. Scale bar, $20 \mu \mathrm{m}$.
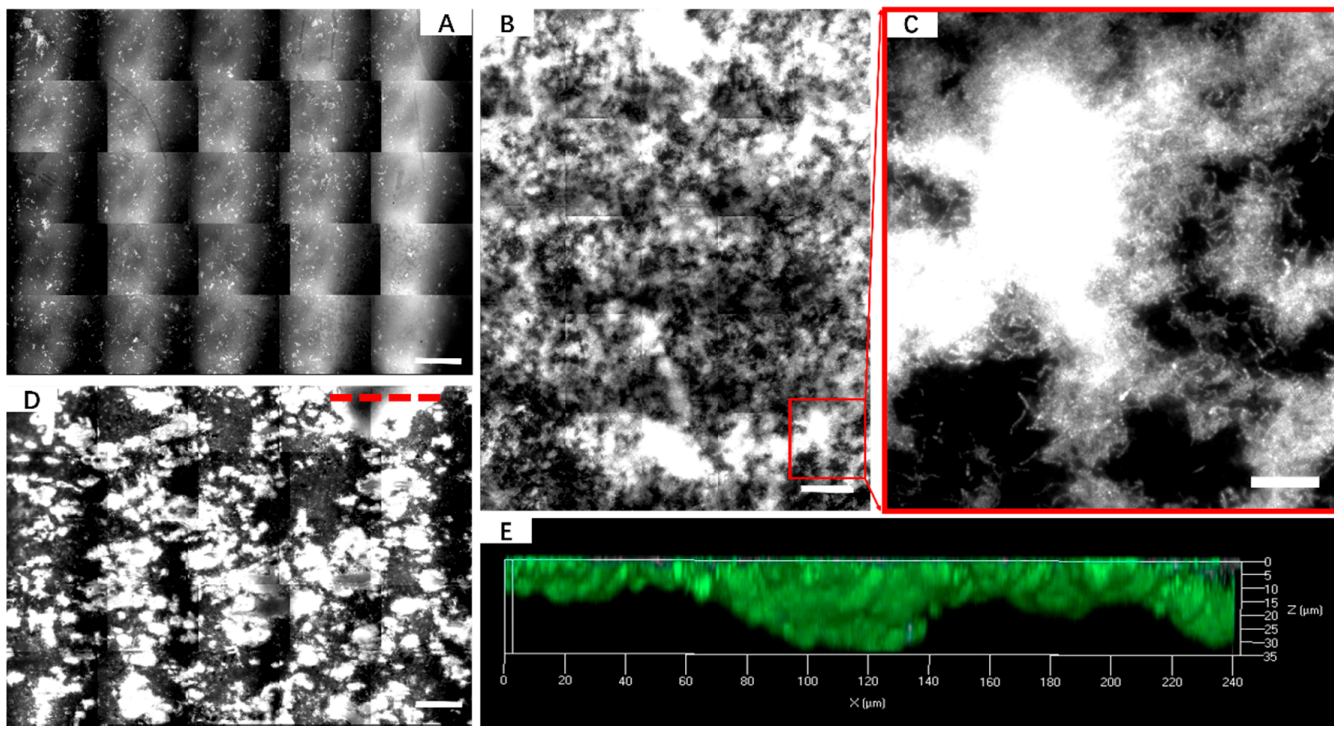

Figure 5. Biofilms of $S b$. thermosulfiooxidans on pyrite slice after one month (A); five months (B) and 10 months (D) incubation; (C) shows the enlarged area from the frame in (B); (E) is the cross-section view of surface topography in the area indicated by the red dashed line in (C); Formation of pits up to $35 \mu \mathrm{m}$ in depth can be seen in (E); Scale bar in (A, B and D) is $100 \mu \mathrm{m}$ and in (C) is $20 \mu \mathrm{m}$. 
A

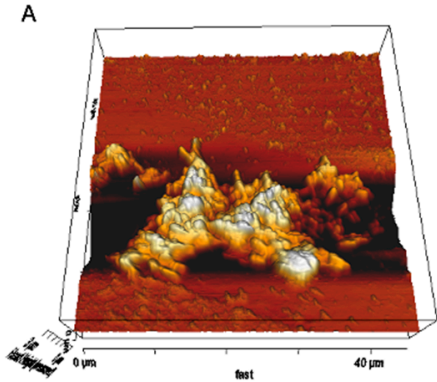

B

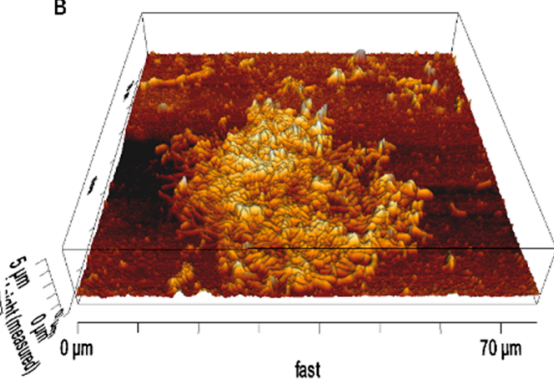

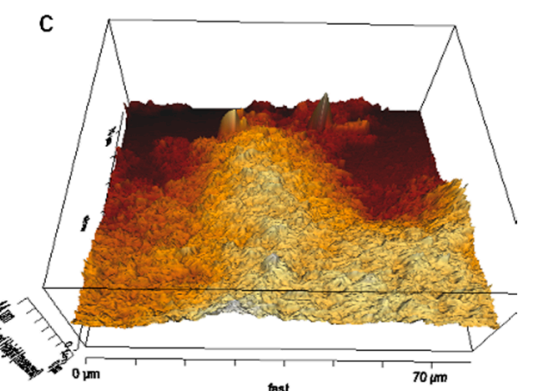

Figure 6. 3D Atomic force microscopy images showing the biofilms of $S b$. thermosulfiooxidans on pyrite slice after one month (A); three months (B) and five months (C) incubation.

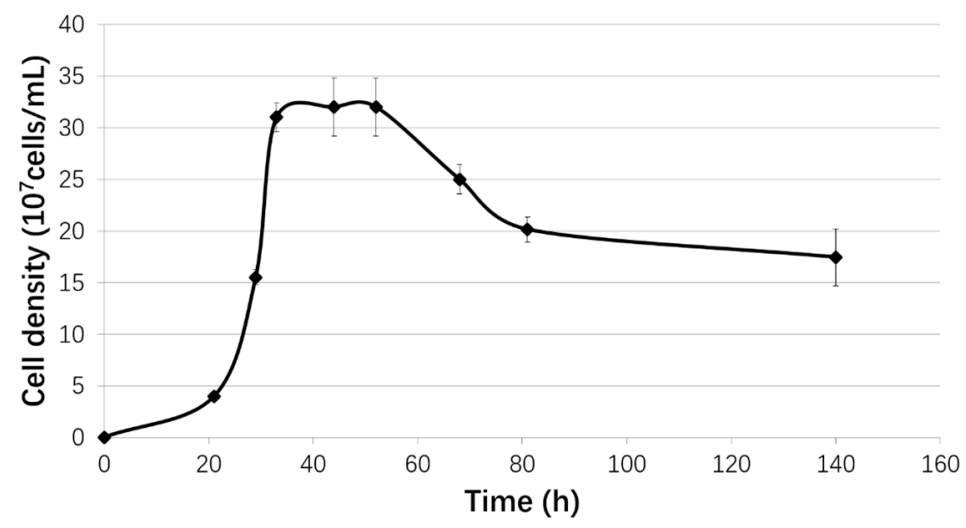

Figure 7. Cell numbers of subcultures of one day biofilms of Sb. thermosulfiooxidans on pyrite in suspension.

\subsection{Bioleaching of Sb. thermosulfidooxidans under Biofilm-Favoring Conditions}

Bioleaching efficiency of $S b$. thermosulfidooxidans, when the medium was regularly exchanged, was evaluated by comparing with the results of cultivation under standard conditions (without any exchange). Figure 8A shows the cell growth and the leached iron as a function of time under standard conditions. A fluctuation of cell numbers was observed in the first $2 \mathrm{~d}$, indicating cell attachment and detachment. Afterwards, the cell density kept decreasing, probably related to the reduced organic nutrition. The concentration of iron ions remained constant during the first $7 \mathrm{~d}$ of the experiment. The largest iron leaching rate was measured between day 7 and 18. Afterwards, the iron ion concentration remained constant again, which indicates that the bioleaching stopped. In total, $195 \mathrm{mg}$ iron ions were leached within 35 days. Figure $8 \mathrm{~B}, \mathrm{C}$ show the cell density and the concentration of iron ion in the spent medium before exchanging with fresh medium, respectively. The results indicate that the cell numbers in the leachate started to decrease considerably from day 18 , but the concentration of iron ion decreased only slowly. Only $4.1 \mathrm{mg}$ iron ions in total were dissolved within $35 \mathrm{~d}$ under these conditions, whereas, under the standard conditions, $195 \mathrm{mg}$ iron ions in total were dissolved. It is noticeable that the bioleaching stopped under the standard conditions after $18 \mathrm{~d}$, whereas bioleaching continued if the medium kept being exchanged. In addition, iron precipitates formed and covered the surface of biofilms and minerals (unpublished data). The degree of oxidation also provides information about the leaching efficiency. As it shown in Figure 5D,E, many pits on the pyrite slices incubated for 10 months can be seen. The confocal laser scanning microscopy images of the pyrite slice surfaces indicate an average depth of the pits of $25 \pm 9 \mu \mathrm{m}$. It is reported that after four months of bioleaching by A. ferrooxidans, many etch pits with an average depth of $320 \mathrm{~nm}$ occurred [32]. Sulfobacilli have a high leaching efficiency if the pit formation rates are compared with 
those of $A$. ferrooxidans: $2500 \mathrm{~nm} /$ month versus $80 \mathrm{~nm} / \mathrm{month}$. In the abiotic control, pits with a depth lower than $2 \mu \mathrm{m}$ were measured (Supplementary Materials, Figure S1).
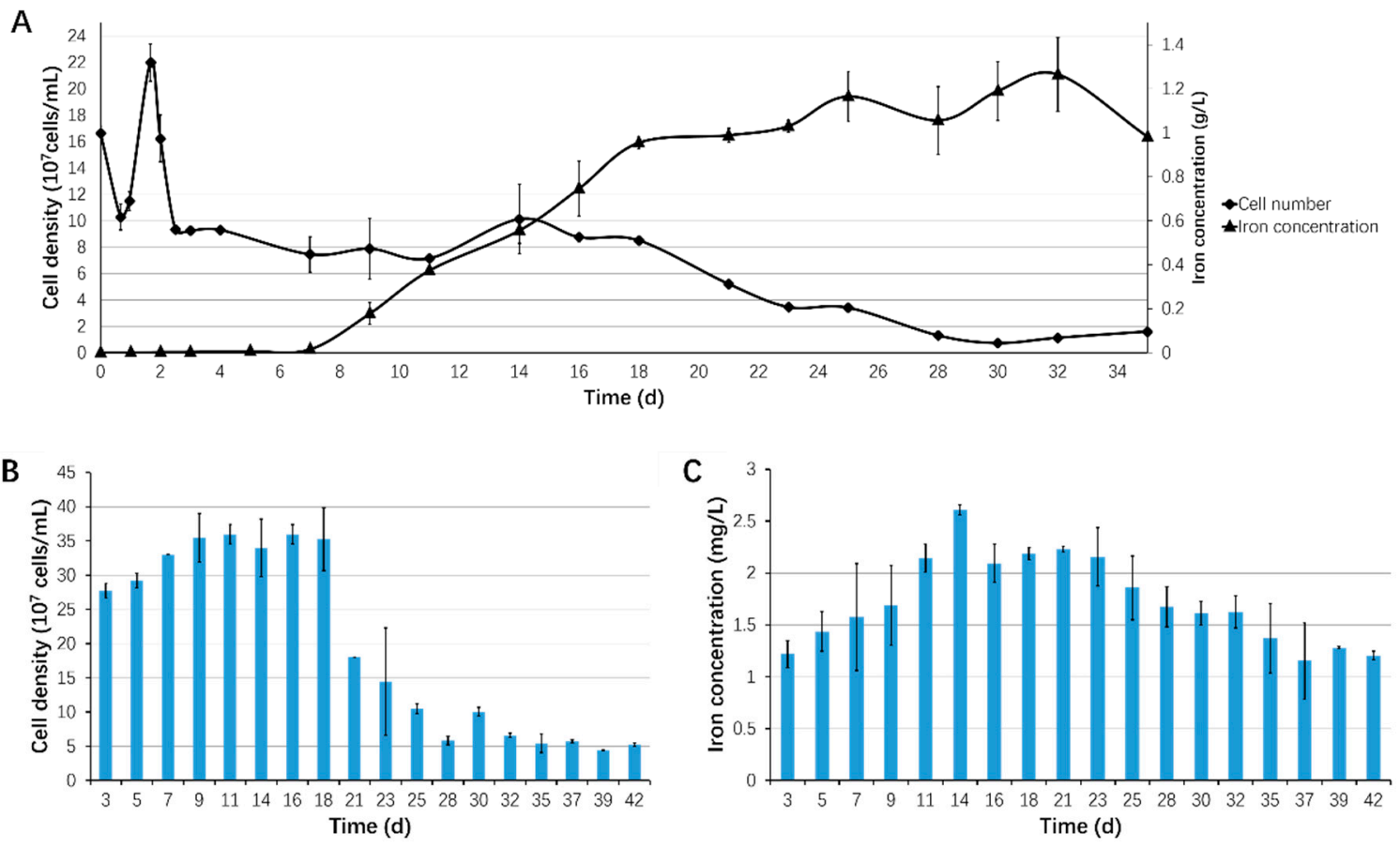

Figure 8. Cell numbers of $S b$. thermosulfiooxidans and leached iron concentration as function of time during bioleaching under standard conditions (A) or regularly changing medium (B and $\mathbf{C})$.

\section{Conclusions}

The low initial adhesion rate of Sb. thermosulfidooxidans to pyrite and its fast detachment demonstrate that this organism is not a good biofilm former under the standard conditions. Strategies of changing the initial $\mathrm{pH}$ of the medium, supplementing an extra energy source, adding ferric ions or phosphate starvation do not show a significantly positive effect on biofilm formation. However, if regularly exchanging exhausted medium with fresh medium, after one month of incubation, robust biofilms can be observed on pyrite surfaces, and bioleaching of pyrite continues. In addition, substratum size has an effect on the architecture of the biofilms.

Supplementary Materials: The following are available online at www.mdpi.com/2075-163X/6/3/71/s1.

Acknowledgments: Qian Li gratefully acknowledges the China Scholarship Council (CSC) for financial funding. We especially thank the two anonymous reviewers for their constructive suggestions that improved this contribution considerably.

Author Contributions: Qian Li performed the laboratory tasks and carried out the experiments. Qian Li wrote the manuscript. Wolfgang Sand and Ruiyong Zhang assisted in preparing the manuscript, and all authors read and approved the final version.

Conflicts of Interest: The authors declare no conflict of interest.

\section{References}

1. Rohwerder, T.; Gehrke, T.; Kinzler, K.; Sand, W. Bioleaching review part A: Progress in bioleaching: Fundamentals and mechanisms of bacterial metal sulfide oxidation. Appl. Microbiol. Biotechnol. 2003, 63, 239-248. [CrossRef] [PubMed]

2. Watling, H. Microbiological advances in biohydrometallurgy. Minerals 2016, 6, 49. [CrossRef]

3. Sand, W.; Gehrke, T.; Jozsa, P.G.; Schippers, A. (Bio)chemistry of bacterial leaching-Direct vs. Indirect bioleaching. Hydrometallurgy 2001, 59, 159-175. [CrossRef] 
4. Gehrke, T.; Telegdi, J.; Thierry, D.; Sand, W. Importance of extracellular polymeric substances from Thiobacillus ferrooxidans for bioleaching. Appl. Environ. Microbiol. 1998, 64, 2743-2747. [PubMed]

5. Brierley, C.L.; Brierley, J.A. Progress in bioleaching: Part B: Applications of microbial processes by the minerals industries. Appl. Microbiol. Biotechnol. 2013, 97, 7543-7552. [CrossRef] [PubMed]

6. Watkin, E.; Keeling, S.; Perrot, F.; Shiers, D.; Palmer, M.-L.; Watling, H. Metals tolerance in moderately thermophilic isolates from a spent copper sulfide heap, closely related to Acidithiobacillus caldus, Acidimicrobium ferrooxidans and Sulfobacillus thermosulfidooxidans. J. Ind. Microbiol. Biotechnol. 2009, 36, 461-465. [CrossRef] [PubMed]

7. Okibe, N.; Gericke, M.; Hallberg, K.B.; Johnson, D.B. Enumeration and characterization of acidophilic microorganisms isolated from a pilot plant stirred-tank bioleaching operation. Appl. Environ. Microbiol. 2003, 69, 1936-1943. [CrossRef] [PubMed]

8. Acosta, M.; Galleguillos, P.; Ghorbani, Y.; Tapia, P.; Contador, Y.; Velásquez, A.; Espoz, C.; Pinilla, C.; Demergasso, C. Variation in microbial community from predominantly mesophilic to thermotolerant and moderately thermophilic species in an industrial copper heap bioleaching operation. Hydrometallurgy 2014, 150, 281-289. [CrossRef]

9. Golovacheva, R.; Karavaĭko, G. Sulfobacillus, a new genus of thermophilic sporulating bacteria. Mikrobiologiia 1978, 47, 815-822. [PubMed]

10. Rawlings, D.E.; Johnson, D.B. The microbiology of biomining: Development and optimization of mineral-oxidizing microbial consortia. Microbiology 2007, 153, 315-324. [CrossRef] [PubMed]

11. Spolaore, P.; Joulian, C.; Gouin, J.; Morin, D.; d'Hugues, P. Relationship between bioleaching performance, bacterial community structure and mineralogy in the bioleaching of a copper concentrate in stirred-tank reactors. Appl. Microbiol. Biotechnol. 2011, 89, 441-448. [CrossRef] [PubMed]

12. Foucher, S.; Battaglia-Brunet, F.; d'Hugues, P.; Clarens, M.; Godon, J.; Morin, D. Evolution of the bacterial population during the batch bioleaching of a cobaltiferous pyrite in a suspended-solids bubble column and comparison with a mechanically agitated reactor. Hydrometallurgy 2003, 71, 5-12. [CrossRef]

13. Becker, T.; Gorham, N.; Shiers, D.; Watling, H. In situ imaging of Sulfobacillus thermosulfidooxidans on pyrite under conditions of variable $\mathrm{pH}$ using tapping mode atomic force microscopy. Process Biochem. 2011, 46, 966-976. [CrossRef]

14. Stoodley, P.; Sauer, K.; Davies, D.; Costerton, J.W. Biofilms as complex differentiated communities. Annu. Rev. Microbiol. 2002, 56, 187-209. [CrossRef] [PubMed]

15. Zhu, J.; Li, Q.; Jiao, W.; Jiang, H.; Sand, W.; Xia, J.; Liu, X.; Qin, W.; Qiu, G.; Hu, Y. Adhesion forces between cells of Acidithiobacillus ferrooxidans, Acidithiobacillus thiooxidans or Leptospirillum ferrooxidans and chalcopyrite. Colloids Surf. B 2012, 94, 95-100. [CrossRef] [PubMed]

16. Dufrene, Y.F. Sticky microbes: Forces in microbial cell adhesion. Trends Microbiol. 2015, 23, 376-382. [CrossRef] [PubMed]

17. Zhu, J.; Wang, Q.; Zhou, S.; Li, Q.; Gan, M.; Jiang, H.; Qin, W.; Liu, X.; Hu, Y.; Qiu, G. Insights into the relation between adhesion force and chalcopyrite-bioleaching by Acidithiobacillus ferrooxidans. Colloids Surf. B 2015, 126, 351-357. [CrossRef] [PubMed]

18. Mackintosh, M. Nitrogen fixation by Thiobacillus ferrooxidans. J. Gen. Microbiol. 1978, 105, 215-218. [CrossRef]

19. Schippers, A.; Jozsa, P.; Sand, W. Sulfur chemistry in bacterial leaching of pyrite. Appl. Environ. Microbiol. 1996, 62, 3424-3431. [PubMed]

20. Zhang, R.; Bellenberg, S.; Neu, T.R.; Sand, W.; Vera, M. The biofilm lifestyle of acidophilic metal/sulfur-oxidizing microorganisms. In Biotechnology of Extremophiles: Advances and Challenges; Rampelotto, H.P., Ed.; Springer International Publishing: Cham, Switzerland, 2016; pp. 177-213.

21. O'Toole, G.A.; Kolter, R. Flagellar and twitching motility are necessary for Pseudomonas aeruginosa biofilm development. Mol. Microbiol. 1998, 30, 295-304. [CrossRef] [PubMed]

22. Varga, J.J.; Therit, B.; Melville, S.B. Type IV pili and the CcpA protein are needed for maximal biofilm formation by the gram-positive anaerobic pathogen Clostridium perfringens. Infect. Immun. 2008, 76, 4944-4951. [CrossRef] [PubMed]

23. Yazdany, S.; Lashkari, K. Effect of pH on sporulation of Bacillus stearothermophilus. Appl. Microbiol. 1975, 30, 1-3. [PubMed] 
24. Watling, H.R.; Perrot, F.A.; Shiers, D.W. Comparison of selected characteristics of Sulfobacillus species and review of their occurrence in acidic and bioleaching environments. Hydrometallurgy 2008, 93, 57-65. [CrossRef]

25. Bellenberg, S.; Barthen, R.; Boretska, M.; Zhang, R.; Sand, W.; Vera, M. Manipulation of pyrite colonization and leaching by iron-oxidizing Acidithiobacillus species. Appl. Microbiol. Biotechnol. 2015, 99, 1435-1449. [CrossRef] [PubMed]

26. Sand, W.; Gerke, T.; Hallmann, R.; Schippers, A. Sulfur chemistry, biofilm, and the (in)direct attack mechanism-A critical evaluation of bacterial leaching. Appl. Microbiol. Biotechnol. 1995, 43, 961-966. [CrossRef]

27. Blake, R.C.; Shute, E.A.; Howard, G.T. Solubilization of minerals by bacteria: Electrophoretic mobility of Thiobacillus ferrooxidans in the presence of iron, pyrite, and sulfur. Appl. Environ. Microbiol. 1994, 60, 3349-3357. [PubMed]

28. Xu, J.; Kim, J.; Danhorn, T.; Merritt, P.M.; Fuqua, C. Phosphorus limitation increases attachment in Agrobacterium tumefaciens and reveals a conditional functional redundancy in adhesin biosynthesis. Res. Microbiol. 2012, 163, 674-684. [CrossRef] [PubMed]

29. Bellenberg, S.; Leon-Morales, C.-F.; Sand, W.; Vera, M. Visualization of capsular polysaccharide induction in Acidithiobacillus ferrooxidans. Hydrometallurgy 2012, 129-130, 82-89. [CrossRef]

30. El-Kirat-Chatel, S.; Boyd, C.D.; O'Toole, G.A.; Dufrêne, Y.F. Single-molecule analysis of Pseudomonas fluorescens footprints. ACS Nano 2014, 8, 1690-1698. [CrossRef] [PubMed]

31. Errington, J. Regulation of endospore formation in Bacillus subtilis. Nat. Rev. Microbiol. 2003, 1, 117-126. [CrossRef] [PubMed]

32. Pace, D.; Mielke, R.; Southam, G.; Porter, T. Scanning force microscopy studies of the colonization and growth of A. ferrooxidans on the surface of pyrite minerals. Scanning 2005, 27, 136-140. [CrossRef] [PubMed]

(C) 2016 by the authors; licensee MDPI, Basel, Switzerland. This article is an open access article distributed under the terms and conditions of the Creative Commons Attribution (CC-BY) license (http:/ / creativecommons.org/licenses/by/4.0/). 